Yuwariah, Y. · A. Ismail · I. N. Hafhittry

\title{
Pertumbuhan dan hasil kacang hijau kultivar Kenari dan No. 129 dalam tumpangsari bersisipan di antara padi gogo
}

\section{Growth and yield of Kenari and No. 129 mungbean cultivars on relay intercropping between of upland rice}

Diterima : Januari 2015/Disetujui : Februari 2015/Dipublikasikan : Maret 2015

CDepartment of Crop Science, Padjadjaran University

\begin{abstract}
The objectives of this experiment was to find the best the timing insertion of two mungbean cultivars on relay intercropping between of upland rice on growth and yield. The experiment was conducted from December 2010 to July 2011 in Ciparanje research station of Agriculture Faculty, Universitas Padjadjaran, Jatinangor Sumedang. A randomized block design used was with three replications and ten treatmens. Those ten treatments consisted of A25 $=$ Kenari cultivar + timing of insertion on 25 days before harvesting upland rice, $\mathrm{A} 20=$ Kenari cultivar + timing of insertion on 20 days before harvesting upland rice, A15 = Kenari cultivar + timing of insertion on 15 days before harvesting upland rice, A10 = Kenari cultivar + timing of insertion on 10 days before harvesting upland rice, A5 $=$ Kenari cultivar + timing of insertion on 5 days before harvesting upland rice, B25 = No.129 cultivar + timing of insertion on 25 days before harvesting upland rice, B20 = No. 129 cultivar + timing of insertion on 20 days before harvesting upland rice, B15 = No.129 cultivar + timing of insertion on 15 days before harvesting upland rice. B10 $=$ N0. 129 cultivar + timing of insertion on 10 days before harvesting upland rice, B5 $=$ No. 129 cultivar + timing of insertion on 5 days before harvesting upland rice. The result showed that the timing of insertion of mungbean between of upland rice with a range on 25, 20 and 15 days before harvesting upland rice gave the better growth and yield of two mungbean cultivars Kenari and No. 129 compared to another timing of insertion, whereas there two cultivars with timing of
\end{abstract}

\footnotetext{
Dikomunikasikan oleh Agus Wahyudin

Yuwariah, Y. ${ }^{1} \cdot$ A. Ismail ${ }^{1} \cdot$ I. N. Hafhittry ${ }^{2}$

1 Staf Fakultas Pertanian Universitas Padjadjaran

2 Alumni Fakultas Pertanian Universitas Padjadjaran

Korespondensi: yuyun_yuwariahas@unpad.ac.id
}

insertion on 25, 20 and 15 days before harvesting upland have higher competitive ratio and produced land equivalent ratio for each cultivar i.e : $1.77 ; 1.53 ; 1.27$ and $1.77 ; 1.53$ and 1.63 .

Keywords : Cultivar - Timming of insertion . Mungbean · Relay intercropping - Upland rice.

Sari Penelitian ini bertujuan untuk mendapatkan waktu penyisipan dua kultivar kacang hijau dalam tumpangsari bersisipan yang terbaik di antara padi gogo terhadap pertumbuhan dan hasil kacang hijau. Percobaan dilaksanakan dari bulan Desember 2010 sampai Juli 2011 di kebun percobaan Ciparanje Fakultas Pertanian Universitas Padjadjaran, Jatinangor, Sumedang. Percobaan ditata dalam Rancangan Acak Kelompok (RAK) dengan tiga ulangan yang terdiri atas 10 perlakuan yaitu $\mathrm{A}_{25}=$ kultivar Kenari + Waktu Penyisipan 25 hari sebelum panen padi gogo, $\mathrm{A}_{20}=$ kultivar Kenari + waktu penyisipan 20 hari sebelum panen padi gogo, $\mathrm{A}_{15}=$ kultivar Kenari + waktu penyisipan 15 hari sebelum panen padi gogo, $\mathrm{A}_{10}=$ kultivar Kenari + waktu penyisipan 10 hari sebelum panen gogo, $A_{5}=$ kultivar Kenari + waktu penyisipan 5 hari sebelum panen gogo, $\mathrm{B}_{25}=$ kultivar No. $129+$ waktu penyisipan 25 hari sebelum panen padi gogo, $B_{20}$ = kultivar No. 129 + waktu penyisipan 20 hari sebelum panen padi gogo, $\mathrm{B}_{15}=$ kultivar No.129 + waktu penyisipan 15 hari sebelum panen padi gogo, $\mathrm{B}_{10}=$ kultivar No. 129 + waktu penyisipan 10 hari sebelum panen padi gogo, $B_{5}=$ kultivar No. 129 + waktu penyisipan 5 hari sebelum panen padi gogo. Hasil penelitian menunjukkan waktu penyisipan kacang hijau di antara padi gogo dengan kisaran 25, 20, dan 15 hari sebelum panen padi gogo, memberikan pertumbuhan dan hasil kedua kultivar Kenari dan No. 129 lebih baik dibandingkan perlakuan 5 dan 10 hari sebelum panen padi gogo, dan menghasilkan 
nisbah kesetaraan lahan dengan besaran masing-masing kultivar 1,77; 1,53; 1,27 dan 1,77; 1,53; dan 1,63.

Kata kunci : kultivar, waktu penyisipan, kacang hijau, relay intercropping, padi gogo.

\section{Pendahuluan}

Upaya mengoptimalkan pemanfaatan lahan dengan tanaman sela dan tumpang sari dapat ditempuh dengan memilih jenis tanaman yang sesuai dengan kondisi iklim mikro. Menurut Chang, 1974; Larcher, 1983 dikutip Kamaluddin (2009), iklim mikro berperan mulai dari proses fotosintesis, respirasi, transpirasi, hingga stimulasi hormonal dan enzim-enzim tanaman yang ada termasuk memanfaatkan intensitas cahaya matahari yang sesuai dengan tanaman sela. Pengembangan padi gogo sebagai tanaman sela pada areal tegakan tanaman, kendala utamanya adalah rendahnya intensitas cahaya matahari yang masuk ke lahan. Hal ini menyebabkan terganggunya proses metabolisme yang berakibat menurunnya laju fotosintesis dan sintesa karbohidrat, sehingga perlu digunakan genotip/ kultivar padi gogo yang toleran naungan sampai dengan 50 \% yang merupakan batas toleransi untuk memanfaatkan lahan yang ternaungi, oleh lahan di bawah tegakan tanaman tahunan.

Jumlah dan distribusi hujan yang cukup memadai, memungkinkan petani dapat menanam sepanjang tahun. Di Indonesia pada lahan kering beriklim basah, umumnya petani telah biasa melaksanakan pola tanam dengan menanam padi gogo secara tumpangsari atau berurutan dengan jagung dilanjutkan menanam kacang-kacangan, sehingga dalam satu tahun, dilaksanakan panen lebih dari satu kali. Pola tanam adalah susunan tata letak dan tata urut tanaman pada sebidang lahan selama periode tertentu (satu tahun) termasuk pengolahan tanah dan masa bera (Yuwariah, 2011).

Pemanfaatan lahan kosong di bawah naungan, yaitu dengan penanaman tanaman sela (padi gogo) toleran naungan dimana padi gogo dapat ditanam dengan komoditas tanaman semusim lainnya, baik tanaman hortikultura maupun palawija (kacang-kacangan) dalam sistem tanam tumpangsari waktu tanam bersamaan ataupun dalam tumpangsari bersisipan (relay intercropping). Hal ini sangat ditentukan oleh daya dukung lingkungan, khususnya ketersediaan air, yang hanya mengandalkan curah hujan di lahan kering. Umumnya petani sudah biasa menanam tumpangsari padi gogo dengan kacang-kacangan dalam sistem tumpangsari waktu tanam bersamaan atau relatif bersamaan. Dalam tumpangsari seperti itu, bila kacang-kacangan merupakan tanaman kedua (padi gogo tanaman utama), dapat dipastikan hasil kacang-kacangan akan rendah, karena adanya keterbatasan dalam pengaturan kerapatan tanaman kacang-kacangan.

Dalam usaha mengoptimalkan penggunaan lahan kering beriklim agak basah atau memiliki periode tanam $\geq 6$ bulan pada lahan di bawah tegakan tanaman tahunan selain menggunakan tanaman padi gogo toleran naungan sebagai tanaman sela, dapat dilanjutkan dengan menanam tanaman yang toleran kekeringan (kacang hijau) dalam sistem tumpangsari bersisipan, yaitu menyisipkan tanaman berikut (kacang hijau) pada saat tanaman sela (padi gogo) dalam kondisi matang fisiologi, sehingga diharapkan dapat meningkatkan produktivitas lahan yang terukur dalam Nisbah Kesetaraan Lahan (NKL).

Melalui penerapan polatanam tumpangsari bersisipan antara padi gogo toleran naungan sebagai tanaman sela dan kacang hijau sebagai tanaman tumpangsari lebih berpeluang dapat meningkatkan produktivitas, karena upaya ini merupakan pemanfaatan daya dukung (ketersediaan air dan fase tumbuh tanaman padi), sehingga hasil masing-masing komoditas, baik padi gogo maupun kacang hijau dapat tumbuh optimal. Hal ini disebabkan dalam pola tanam tumpangsari bersisipan, yaitu dengan menyisipkan kacang hijau di antara tanaman padi gogo, pada saat itu padi gogo berada dalam fase generatif, dan kerapatan masing-masing tanaman berada pada kerapatan normal, seperti halnya pada tanaman tunggal, sehingga efek kompetisi antara padi gogo dan kacang hijau dapat diperkecil, dan daya dukung lainnya seperti ketersediaan air dari curah huajn masih tersedia. Masalahnya kapan waktu penyisipan kacang hijau di antara padi gogo yang berpengaruh paling baik terhadap pertumbuhan dan hasil kedua jenis tanaman tersebut.

\section{Bahan dan Metode}

Percobaan dilaksanakan di Kebun Percobaan Ciparanje Fakultas Pertanian Universitas Padja-

Yuwariah, dkk. : Pertumbuhan dan hasil kacang hijau kultivar Kenari dan No. 129 dalam tumpangsari bersisipan di antara padi gogo 
djaran, Jatinangor Sumedang. Lokasi percobaan pada ketinggian $\pm 750 \mathrm{~m}$ di atas permukaan laut (dpl), memiliki ordo tanah Inceptisols dengan tipe iklim berdasarkan curah hujan termasuk $C_{3}$ menurut klasifikasi Oldeman, 1975. Persiapan dan penanaman padi gogo dilaksanakan dari bulan Desember 2010 sampai April 2011, sedangkan lima interval waktu penyisipan kacang hijau di antara padi gogo dilaksanakan dari bulan April sampai Juli 2011.

Bahan yang digunakan dalam percobaan ini adalah benih padi gogo kultivar Dodokan, koleksi Laboratorium Pemuliaan Tanaman Fakultas Pertanian Unpad yang terseleksi paling toleran naungan dari 40 genotip yang dicoba pada percobaan sebelumnya dan benih kacang hijau kultivar Kenari dan No. 129.

Pupuk urea (200 kg/ha), SP 36 (100 kg/ha), dan $\mathrm{KCl}(100 \mathrm{~kg} / \mathrm{ha}$, digunakan untuk tanaman padi, dan insektisida Furadan 3G, Decis 2,5 E C dan Dithane M-45. Selain itu digunakan paranet (naungan 50\%) yang merupakan simulasi tanaman sela dan tumpangsari bersisipan di bawah tegakan tanaman tahunan. Percobaan di tata dalam Rancangan Acak Kelompok (RAK), yang terdiri dari 10 perlakuan dan tiga ulangan. Kesepuluh perlakuan sebagai berikut : $\mathrm{A}_{25}=$ kultivar Kenari, waktu penyisipan 25 hari sebelum panen padi gogo, $\mathrm{A}_{20}=$ kultivar Kenari, waktu penyisipan 20 hari sebelum panen padi gogo, $\mathrm{A}_{15}=$ kultivar Kenari, waktu penyisipan 15 hari sebelum panen padi gogo, $\mathrm{A}_{10}=$ kultivar Kenari, waktu penyisipan 10 hari sebelum panen padi gogo, $\mathrm{A}_{5}=$ kultivar Kenari, waktu penyisipan 5 hari sebelum panen padi gogo, $\mathrm{B}_{25}$ =kultivar No. 129, waktu penyisipan 25 hari sebelum panen padi gogo , $\mathrm{B}_{20}=$ kultivar No. 129 , waktu penyisipan 20 hari sebelum panen padi gogo, $B_{15}=$ kultivar No. 129, waktu penyisipan 15 hari sebelum panen padi gogo, $B_{10}$ $=$ kultivar No. 129, waktu penyisipan 10 hari sebelum panen padi gogo, $B_{5}=$ kultivar No. 129, waktu penyisipan 5 hari sebelum panen padi gogo. Pengaruh perlakuan terhadap pertumbuhan dan hasil kacang hijau dianalisis dengan analisis ragam menggunakan uji $\mathrm{F}$ pada taraf kepercayaan 95\%, dan dianjutkan dengan uji jarak Berganda Duncan pada taraf 5\%.

Pengamatan terdiri dari pengamatan penunjang dan pengamatan utama. Pengamatan dilakukan sesuai fase dari umur tanaman kacang hijau. Pengamatan penunjang terdiri dari : analisis tanah awal, jenis hama dan penyakit tanaman selama percobaan, jenis gulma yang tumbuh pada pertanaman hasil padi gogo yang disisipi kacang hijau, dan iklim mikro (Intensitas cahaya, curah hujan, suhu, dan kelembaban). Pengamatan utama meliputi : komponen pertumbuhan (tinggi tanaman dan indeks luas daun), komponen hasil dan hasil (jumlah cabang produktif, jumlah polong isi dan polong hampa per tanaman, jumlah biji per tanaman, bobot 100 butir biji, dan bobot biji kering perpetak), serta komponen tumpangsari bersisipan (nisbah kompetisi dan nisbah kesetaraan lahan).

\section{Hasil dan Pembahasan}

Hasil analisis tanah ordo Inceptisol memiliki tekstur liat berdebu dengan komposisi pasir : debu : liat sebesar $12 \%$ : 41\% : 47\%. Karakter kimianya menunjukkan tanah bereaksi agak masam dengan $\mathrm{pH}$ sebesar 6,25 dan memiliki $\mathrm{C} / \mathrm{N}=12$ (termasuk kategori sedang). $\mathrm{pH}$ tanah sebesar 6,25 sesuai dengan syarat tumbuh kacang hijau, seperti dikemukakan Purwono dan Rudi Hartono (2008), bahwa kemasaman tanah yang dipelukan untuk pertumbuhan optimal tanaman kacang hijau antara 5,5 - 6,5.

Selama percobaan berlangsung, jenis hama yang menyerang kacang hijau, yaitu uret (Lepidiota stigma L.), ulat penggulung daun (Lamprosema indicata F.) dan ulat grayak (Spodoptera litura F.). Untuk kedua kultivar kacang hijau dengan waktu penyisipan 25 hari sebelum panen padi gogo $\left(\mathrm{A}_{25}\right.$ dan $\left.\mathrm{B}_{25}\right)$ sangat rentan terkena serangan hama uret, karena cuaca di sekitar pertanaman lembab (kelembaban udara $>80 \%$, menyebabkan intensitas serangan mencapai $\pm 20 \%)$. Hama tersebut dikendalikan secara kimiawi dengan Furadan 3G (17 kg/ha) atau sebanyak 0,11 gram per lubang tanam, dimasukkan ke dalam tanah di sebelah tanaman kacang hijau. Hal yang sama terjadi pada serangan ulat grayak (Spodoptera litura F.), hama tersebut menyerang tanaman umur 4 mst. Hama ulat grayak hampir terdapat di seluruh tanaman kacang hijau dengan perlakuan kultivar dan waktu penyisipan, dan intensitas serangan mencapai $\pm 20 \%$. Hama tersebut dikendalikan dengan penyemprotan insektisida Decis 2,5 EC dengan konsentrasi 0,5 $\mathrm{ml} \mathrm{L}^{-1}$, dan insektisida Curacon $500 \mathrm{EC}$ dengan konsentrasi 2 ml. $\mathrm{L}^{-1}$, dalam interval waktu penyemprotan satu minggu sekali. Pengendalian yang sama diberlakukan pula terhadap hama ulat penggulung daun, tingkat serangan \pm $5 \%$, dan hanya terdapat pada beberapa perla- 
kuan saja. Penyakit yang menyerang tanaman kacang hijau selama percobaan yaitu bercak daun yang disebabkan oleh cendawan (Ercospora sinensis).

Perkembangan penyakit tersebut dipengaruhi lingkungan (cuaca lembab). Kondisi saat percobaan berlangsung untuk ketiga waktu penyisipan 25, 20 dan 15 hari sebelum panen padi gogo, kelembaban $>80 \%$ pada fase pertumbuhan dan pembungaan; demikian pula adanya hujan yang terjadi selama fase itu, dapat membantu penyebaran jamur ke tanaman kacang hijau lainnya. Penyakit ini di atasi dengan menggunakan Dithane M-45 dengan konsentrasi 2 g L-1, sehingga mengurangi gangguan terhadap pertumbuhan tanaman. Beberapa gulma dominan diantaranya: babadotan (Ageratum conyzoides), putri malu (Mimosa pudica) dan teki (Ciperus rotundus). Pengendalian yang dilakukan yaitu dengan cara mekanik, yakni mencabut gulma yang tumbuh pada areal pertanaman.

Kondisi iklim mikro yang terjadi selama percobaan kacang hijau seperti ditunjukkan oleh besarnya intersepsi radiasi surya oleh tajuk tanaman terhadap radiasi yang diteruskan oleh tajuk tanaman berkisar dari 27,15 - 91,71\% atau setara dengan 178,55 - 444,05 ft cd, (selengkapnya tercantum pada Tabel 1).

Pada Tabel 1. ditunjukkan rata-rata besarnya radiasi surya yang datang ke tajuk tanaman kacang hijau, yang diteruskan oleh tajuk tanaman, dan yang diintersepsi oleh tanaman kacang hijau sejak umur 1 mst, 2 mst, dan 3 mst, dalam kondisi ternaungi oleh padi gogo dan paranet. Adapun waktu pengukuran dilaksanakan pada waktu-waktu pukul 09.00, pukul 12.00 dan pukul 15.00 WIB.

Intersepsi radiasi surya sangat ditentukan oleh besarnya ILD dan t. Semakin besar ILD dan semakin kecil $t$, maka intersepsi radiasi surya oleh tanaman umumnya akan semakin besar. Suhu selama percobaan berkisar dari $29{ }^{\circ} \mathrm{C}$ sampai $33{ }^{\circ} \mathrm{C}$, kelembaban relatif (RH) berkisar dari 60 sampai $90 \%$, dan untuk curah hujan selama percobaan berada dalam kisaran (4140,3) mm; selengkapnya tertera pada Tabel 2.

Hasil padi gogo datanya tidak dianalisis statistik, data ini digunakan untuk menghitung Nisbah Kompetisi (NK) dan Nisbah Kesetaraan Lahan (NKL). Selengkapnya tertera pada Tabel 3.

Tanaman padi gogo dipanen pada umur 130 hari setelah tanam. Hasil tanam tunggal padi gogo, yaitu 1959,65 g/petak(1,3 t.ha-1), sedangkan hasil tanam tumpangsari bersisipan padi gogo, yaitu berkisar antara 1115,50 1956,62 g/petak (0,8 - 1,3 t.ha-1). Menurut Biro Pusat Statistik Indonesia (2005), produktivitas padi gogo di Indonesia relatif masih rendah, berkisar antara 1,68 - 2,96 $\mathrm{t}_{\text {ha }} \mathrm{-}^{-1}$ dengan rata-rata $2,58 \mathrm{t}$ ha-1 $^{-1}$. Hasil penelitian lebih rendah yaitu 1,3 $\mathrm{t} / \mathrm{ha}$, disebabkan pengaruh naungan paranet $50 \%$, namun demikian menunjukkan adanya toleransi dari padi gogo terhadap naungan sebesar $50 \%$.

Tabel 1. Rata-rata Radiasi Surya yang Diterima oleh Tajuk Tanaman, yang Diteruskan oleh Tajuk ke dalam Tajuk Tanaman, dan yang Diintersepsi oleh Tanaman Kacang Hijau Atas Dasar ILD dan $\mathrm{t}$.

\begin{tabular}{|c|c|c|c|c|c|c|}
\hline \multirow[t]{3}{*}{ Perlakuan } & \multicolumn{6}{|c|}{ Rata-rata radiasi surya } \\
\hline & \multirow{2}{*}{$\begin{array}{c}\text { Diterima } \\
\text { tajuk tanaman } \\
\left(\mathrm{I}_{\mathrm{o}}\right)(\mathrm{Lux})\end{array}$} & \multirow[t]{2}{*}{ ILD } & \multirow{2}{*}{$\begin{array}{c}\text { Diteruskan oleh } \\
\text { tajuk tanaman } \\
\left(I_{a}\right)(L u x)\end{array}$} & \multirow{2}{*}{$\begin{array}{l}\text { Koefisien } \\
\text { penerusan } \\
(\mathrm{t})\end{array}$} & \multicolumn{2}{|c|}{$\begin{array}{l}\text { Intersepsi oleh tajuk } \\
\text { tanaman }\left(\mathrm{I}_{\text {Int }}\right)\end{array}$} \\
\hline & & & & & $(\operatorname{Lux})$ & $(\mathrm{ft} \mathrm{cd})$ \\
\hline $\mathrm{A}_{25}$ & 10777,50 & 1,03 & 6169,85 & 0,57 & 4607,38 & 428,20 \\
\hline $\mathrm{A}_{20}$ & 9442,89 & 0,93 & 5322,64 & 0,56 & 4119,93 & 382,89 \\
\hline $\mathrm{A}_{15}$ & 8811,67 & 0,86 & 4966,84 & 0,59 & 3648,91 & 339,12 \\
\hline $\mathrm{A}_{10}$ & 8540,72 & 0,70 & 5491,72 & 0,64 & 3049,04 & 283,37 \\
\hline $\mathrm{A}_{5}$ & 8417,45 & 0,41 & 6126,68 & 0,73 & 2291,23 & 212,94 \\
\hline $\mathrm{B}_{25}$ & 9987,33 & 1,20 & 5209,87 & 0,52 & 4777,94 & 444,05 \\
\hline $\mathrm{B}_{20}$ & 8566,22 & 0,97 & 4681,25 & 0,55 & 3884,78 & 361,04 \\
\hline $\mathrm{B}_{15}$ & 8629,00 & 0,72 & 5215,16 & 0,64 & 3413,63 & 317,25 \\
\hline $\mathrm{B}_{10}$ & 10300,23 & 0,68 & 6421,19 & 0,62 & 3879,07 & 360,51 \\
\hline $\mathrm{B}_{5}$ & 8998,56 & 0,31 & 7077,12 & 0,79 & 1921,19 & 178,55 \\
\hline
\end{tabular}

Keterangan : ft cd = foot candle; 1 foot candle = 10,76 lux; hspp : hari sebelum panen padi gogo 
Tabel 4. Pengaruh Kultivar dan Waktu Penyisipan Tanaman Kacang Hijau di Antara Padi Gogo terhadap Tinggi Tanaman Umur 2 mst, 4 mst, 6 mst dan Indeks Luas Daun Umur 5 mst.

\begin{tabular}{|c|c|c|c|c|}
\hline \multirow{2}{*}{ Perlakuan } & \multicolumn{3}{|c|}{ Tinggi Tanaman (cm) } & \multirow{2}{*}{$\frac{\text { Indeks Luas Daun }}{5 \mathrm{mst}}$} \\
\hline & $2 \mathrm{mst}$ & $4 \mathrm{mst}$ & $6 \mathrm{mst}$ & \\
\hline $\mathrm{A}_{25}$ & 24,10 ef & $27,60 \mathrm{~cd}$ & $29,40 \mathrm{abc}$ & $1,03 \mathrm{ab}$ \\
\hline $\mathrm{A}_{20}$ & $23,30 \mathrm{de}$ & $31,40 \mathrm{e}$ & $34,47 \mathrm{~cd}$ & $0,93 \mathrm{ab}$ \\
\hline $\mathrm{A}_{15}$ & 19,07 cde & $26,53 \mathrm{c}$ & $31,40 \mathrm{bc}$ & $0,86 \mathrm{ab}$ \\
\hline $\mathrm{A}_{10}$ & $15,47 \mathrm{~b}$ & $23,07 \mathrm{~b}$ & $26,00 \mathrm{ab}$ & $0,70 \mathrm{ab}$ \\
\hline $\mathrm{A}_{5}$ & $10,00 \mathrm{a}$ & $18,00 \mathrm{a}$ & $23,60 \mathrm{a}$ & $0,41 \mathrm{a}$ \\
\hline $\mathrm{B}_{25}$ & $24,30 \mathrm{f}$ & $26,63 \mathrm{c}$ & $29,07 \mathrm{abc}$ & $1,20 \mathrm{~b}$ \\
\hline $\mathrm{B}_{20}$ & $24,80 \mathrm{f}$ & 30,47 de & $29,33 \mathrm{~d}$ & $0,97 \mathrm{ab}$ \\
\hline $\mathrm{B}_{15}$ & $18,57 \mathrm{~cd}$ & $04,87 \mathrm{bc}$ & $28,67 \mathrm{abc}$ & $0,72 \mathrm{ab}$ \\
\hline $\mathrm{B}_{10}$ & $15,07 \mathrm{~b}$ & $24,20 \mathrm{bc}$ & 30,87 bc & $0,68 \mathrm{ab}$ \\
\hline $\mathrm{B}_{5}$ & $11,33 \mathrm{ab}$ & $19,47 \mathrm{a}$ & $23,87 \mathrm{a}$ & $0,31 \mathrm{a}$ \\
\hline
\end{tabular}

Keterangan : Nilai rata-rata perlakuan yang diikuti dengan huruf yang sama pada kolom yang sama, menunjukkan tidak berbeda nyata menurut uji jarak berganda Duncan pada taraf nyata 5\%. hspp $=$ hari sebelum panen padi gogo.

Selain faktor radiasi surya, tinggi tanaman untuk kedua kultivar kacang hijau Kenari dan No. 129 yang disisipkan 25, 20 dan 15 hari sebelum panen padi gogo pada umur 2 mst, 4 mst dan 6 mst, ditunjukkan lebih tinggi dibandingkan kedua waktu sisip lainnya (10 dan 5 hari sebelum panen padi gogo), seperti tertera pada Tabel 4 . Hal ini disebabkan ketiga waktu penyisipan tersebut masih mendapatkan lingkungan faktor tumbuh seperti suhu, kelembaban, dan ketersedian air yang lebih baik dibandingkan dengan kedua perlakuan lainnya, yaitu 10 dan 5 hari sebelum panen padi gogo (Tabel 2).

Pengaruh kultivar dan waktu penyisipan tanaman kacang hijau di antara padi gogo terhadap ILD, ditunjukkan pada Tabel 4. Pada tabel tersebut terlihat bahwa secara umum pengaruh kultivar dan waktu penyisipan kacang hijau, tidak menunjukkan perbedaan nyata terhadap ILD (berkisar dari 0,31-1,20). Perbedaan hanya terjadi pada perlakuan kultivar No. 129 yang disisipkan 25 hari sebelum panen padi gogo $\left(B_{25}\right)$ dengan perlakuan penyisipan 5 hari sebelum panen padi gogo $\left(\mathrm{B}_{5}\right)$, masing-masing sebesar 1,20 vs 0,31 .

Capaian rendahnya ILD kedua kultivar kacang hijau, disebabkan oleh rendahnya intensitas radiasi surya yang diintersep tanaman (Tabel 1.). Berdasarkan beberapa penelitian antara lain pada tanaman kentang (Sale, 1976), gandum (Fisher, 1975), Baccharis halifolia (Poneta, 1977) dan Trifolium subterraneum L. (Collins, Rossiter dan Monreal, 1978), serta beberapa jenis tanaman pengganggu (Shetty, Sivakumar, dan Ramm (1982), menyimpulkan bahwa pengurangan intersepsi radiasi surya secara umum mengganggu pertumbuhan pupus dan akar, mengurangi luas daun, serta akan mengakibatkan rendahnya hasil.

Seperti halnya yang terjadi pada tinggi tanaman, ILD pun selain dipengaruhi oleh besarnya intersepsi radiasi surya, juga ketiga waktu penyisipan kacang hijau di antara padi gogo untuk kedua kultivar, dengan kisaran waktu penyisipan 25, 20, dan 15 hari sebelum panen padi gogo, masih mendapatkan lingkungan faktor tumbuh atau iklim mikro yang terbentuk lebih baik dibandingkan kedua perlakuan lainnya seperti suhu, kelembaban dan ketersediaan air (Tabel 2).

Pada Tabel 5. ditunjukkan pengaruh kultivar dan waktu penyisipan tanaman kacang hijau di antara padi gogo terhadap komponen hasil dan hasil.

Tanaman kacang hijau dapat tumbuh baik serta memberikan hasil yang tinggi apabila selama pertumbuhannya syarat tumbuh yang sesuai dipenuhi. Tanaman kacang hijau termasuk tanaman $C_{3}$ (Carlson, 1980), dan cenderung menyukai radiasi surya yang relatif tinggi. Titik kejenuhan cahaya bagi tanaman "sun species" (sebagian besar tanaman lapang jenuh pada $2500 \mathrm{ft} \mathrm{cd}$ ) seperti halnya kacang hijau, dan "shade species" jenuh pada $\pm 1000 \mathrm{ft} \mathrm{cd}$ (Justika Baharsyah, 1991), sedangkan dalam penelitian ini kacang hijau menerima cekaman yang cukup berat selama fase pertumbuhannya, yaitu dengan adanya naungan dari paranet dan padi gogo, dengan intersepsi radiasi surya oleh tajuk tanaman berkisar dari $(178,55$ - 444,05) ft cd, seperti tertera pada Tabel 1. 
Tabel 5. Pengaruh Kultivar dan Waktu Penyisipan Tanaman Kacang Hijau di Antara Padi Gogo Terhadap Komponen Hasil dan Hasil.

\begin{tabular}{cccccccc}
\hline \hline Perlakuan & $\begin{array}{c}\text { Jumlah } \\
\text { cabang } \\
\text { produktif } \\
\text { (buah) }\end{array}$ & $\begin{array}{c}\text { Jumlah } \\
\text { polong isi } \\
\text { per } \\
\text { tanaman } \\
\text { (buah) }\end{array}$ & $\begin{array}{c}\text { Jumlah } \\
\text { polong } \\
\text { hampa per } \\
\text { tanaman } \\
\text { (buah) }\end{array}$ & $\begin{array}{c}\text { Jumlah biji } \\
\text { per } \\
\text { tanaman } \\
\text { (butir) }\end{array}$ & $\begin{array}{c}\text { bobot 100 } \\
\text { butir biji } \\
\text { (g) }\end{array}$ & $\begin{array}{c}\text { Bobot biji } \\
\text { kering per } \\
\text { petak } \\
\text { (g) }\end{array}$ & $\begin{array}{c}\text { Perkiraan } \\
\text { bobot biji } \\
\text { kering per } \\
\text { hektar } \\
\text { (t) }\end{array}$ \\
\hline $\mathrm{A}_{25}$ & $2,47 \mathrm{~b}$ & $5,20 \mathrm{~b}$ & $0,41 \mathrm{a}$ & $30,53 \mathrm{~b}$ & $6,35 \mathrm{~d}$ & $877,40 \mathrm{~b}$ & 0,6 \\
$\mathrm{~A}_{20}$ & $2,80 \mathrm{~b}$ & $4,53 \mathrm{~b}$ & $0,53 \mathrm{a}$ & $28,61 \mathrm{~b}$ & $6,45 \mathrm{~cd}$ & $731,16 \mathrm{~b}$ & 0,5 \\
$\mathrm{~A}_{15}$ & $2,57 \mathrm{~b}$ & $4,93 \mathrm{~b}$ & $0,58 \mathrm{a}$ & $24,80 \mathrm{~b}$ & $6,80 \mathrm{~d}$ & $584,93 \mathrm{~b}$ & 0,4 \\
$\mathrm{~A}_{10}$ & $1,80 \mathrm{a}$ & $3,13 \mathrm{a}$ & $0,44 \mathrm{a}$ & $21,83 \mathrm{a}$ & $5,52 \mathrm{ab}$ & $438,69 \mathrm{a}$ & 0,3 \\
$\mathrm{~A}_{5}$ & $1,68 \mathrm{a}$ & $3,20 \mathrm{a}$ & $0,69 \mathrm{a}$ & $14,93 \mathrm{a}$ & $4,85 \mathrm{a}$ & $188,90 \mathrm{a}$ & 0,1 \\
$\mathrm{~B}_{25}$ & $2,56 \mathrm{~b}$ & $8,27 \mathrm{~b}$ & $0,37 \mathrm{a}$ & $46,80 \mathrm{~b}$ & $6,07 \mathrm{bcd}$ & $888,10 \mathrm{~b}$ & 0,6 \\
$\mathrm{~B}_{20}$ & $2,33 \mathrm{~b}$ & $7,20 \mathrm{~b}$ & $0,46 \mathrm{a}$ & $47,48 \mathrm{~b}$ & $5,72 \mathrm{abc}$ & $828,50 \mathrm{~b}$ & 0,5 \\
$\mathrm{~B}_{15}$ & $2,89 \mathrm{~b}$ & $5,30 \mathrm{~b}$ & $0,52 \mathrm{a}$ & $37,52 \mathrm{~b}$ & $5,22 \mathrm{abc}$ & $740,08 \mathrm{~b}$ & 0,5 \\
$\mathrm{~B}_{10}$ & $1,86 \mathrm{a}$ & $3,66 \mathrm{a}$ & $0,62 \mathrm{a}$ & $22,27 \mathrm{a}$ & $4,68 \mathrm{a}$ & $443,27 \mathrm{~b}$ & 0,3 \\
$\mathrm{~B}_{5}$ & $1,91 \mathrm{a}$ & $3,60 \mathrm{a}$ & $0,65 \mathrm{a}$ & $14,55 \mathrm{a}$ & $4,61 \mathrm{a}$ & $208,40 \mathrm{a}$ & 0,1 \\
\hline \hline
\end{tabular}

Keterangan : Nilai rata-rata perlakuan yang diikuti dengan huruf yang sama pada kolom yang sama, menunjukkan tidak berbeda nyata menurut uji jarak berganda Duncan pada taraf nyata $5 \%$.

hspp : hari sebelum panen padi gogo

Untuk memahami lebih dalam mengenai pengaruh kultivar dan waktu penyisipan kacang hijau di antara padi gogo terhadap komponen hasil dan hasil, dengan kisaran waktu penyisipan 25, 20, 15, 10 dan 5 hari sebelum panen padi gogo, perlu mengkaji kondisi ling-kungan iklim mikro pada setiap fase pertumbuhan dan perkembangan kacang hijau yang ditampilkan pada Tabel 2. Selama fase pertumbuhan (umur 0-30 hari setelah tanam), kedua kultivar kacang hijau Kenari dan No. 129, semua berada dalam kisaran suhu optimal $29-30{ }^{\circ} \mathrm{C}$, kecuali perlakuan 5 hari sebelum panen padi gogo $\left(\mathrm{A}_{5}\right.$ dan $\left.B_{5}\right)$. Akibat naungan paranet dan padi gogo, kelembaban relatif mencapai $>80 \%$, melebihi kondisi optimum 50-80 \% (Poehlman, 1991). Tampaknya yang paling kritis selama fase pertumbuhan kacang hijau, adalah ketersediaan air. Tabel 2 menunjukkan bahwa ketiga waktu penyisipan kacang hijau di antara padi gogo 25 , 20, dan 15 hari sebelum panen padi gogo untuk kedua kultivar Kenari dan No. 129 menerima pengairan yang cukup sepenuhnya berasal dari curah hujan masing-masing sebesar 137,3, 140,3 dan $113,8 \mathrm{~mm}$ dengan distribusi yang merata. Berbeda dengan kedua perlakuan lainnya, 10 dan 5 hari sebelum panen padi gogo, hanya menerima 22,3 dan 18,6 mm. Kondisi ini tentu saja akan berdampak buruk pada perkembangan selanjutnya. Akibat dari kekurangan air telah ditunjukkan pada tinggi tanaman dan ILD (Tabel 4).

Pada fase berikutnya yaitu fase generatif, pembungaan $>30-45$ hari dan pengisian polong $>$ 45-55 hari sampai dengan pemasakan, umumnya suhu berada di atas $30^{\circ} \mathrm{C}$ (melebihi suhu optimum $28-30{ }^{\circ} \mathrm{C}$ ), kecuali pada fase pembungaan, kedua kultivar kacang hijau Kenari dan No. 129, dengan kisaran waktu penyisipan 25, 20, dan 15 hari sebelum panen padi gogo berada dalam kisaran suhu optimum $\left(29-30^{\circ} \mathrm{C}\right)$.

Suhu mempengaruhi tanaman melalui laju proses-proses metabolisme. Pengaruh suhu terutama terlihat pada laju perkembangan tanaman, seperti pada perkecambahan, pembentukan daun, dan inisiasi organ reproduktif. Suhu merupakan salah satu faktor utama dari lingkungan yang menentukan besarnya pemanjangan dan pertambahan luas organ tanaman melalui translokasi asimilat dari daun, batang atau organ lain. Pengaruh suhu yang terlalu rendah atau terlalu tinggi pada pertumbuhan tanaman bervariasi bergantung pada tahap pertumbuhan tanaman, misalnya pada tanaman padi dari kegagalan berkecam-bah, tumbuh kerdil, warna daun pucat, anakan terganggu, keterlambatan berbunga, kehampaan gabah dan gangguan terhadap kemasakan (Justika Baharsyah, 1981). Hal serupa terjadi pada kacang hijau, suhu yang tidak optimal menyebabkan gangguan terhadap pembentukan cabang produktif, terjadinya polong hampa, hambatan pembentukan polong isi, yang kesemuanya akan menurunkan bobot biji per tanaman, bobot biji per hektar, dan bobot 100 butir, seperti ditunjukkan pada Tabel 5.

Selain faktor suhu, kelembaban pun berperan penting dalam menentukan produktivitas kacang hijau. Dengan adanya naungan dari 
paranet pada fase pembungaan, kedua kultivar kacang hijau Kenari dan No. 129 berada dalam kelembaban di atas $80 \%$ bagi tiga waktu penyisipan kacang hijau di antara padi gogo, yaitu 25, 20, dan 15 hari sebelum panen padi gogo. Sekalipun pengaruh kelembaban lebih banyak secara tidak langsung terhadap pertumbuhan dan produktivitas tanaman, namun pengaruh langsung dalam proses pembungaan, khususnya kegagalan proses persarian (Ahmad Bey, dan Irsal Las, 1991). Pernyataan ini relevan dengan hasil penelitian yang terjadi, bahwa gangguan terhadap persarian pada tiga waktu penyisipan yang disebabkan oleh kelembaban di atas $80 \%$ ditambah dengan rendahnya intersepsi radiasi surya oleh tajuk tanaman selama fase pertumbuhan dan perkembangan 317,25 - 444,05 $\mathrm{ft}$ cd (Tabel 1) hal ini dapat menurunkan hasil. Sekalipun dukungan suhu dan ketersediaan air relatif memadai pada fase itu (Tabel 2), namun kedua kultivar kacang hijau Kenari dan No. 129 tidak dapat mempertahankan stabilitas hasil, yang hanya mencapai $0,4-0,6$ ton per hektar. Penyebab keadaan ini karena suhu dan ketersediaan air pada fase-fase berikutnya (pengisian polong dan pemasakan), berada dalam keadaan tidak optimum, sedang-kan kekurangan air pada fase pembentukan polong, merupakan fase paling kritis, dan menyebabkan persentase sterilitas yang tinggi pada tanaman yang pada akhirnya menurunkan peroduktivitas (Justika Baharsyah, 1991).

Kondisi yang lebih ekstrim, terjadi pada kedua kultivar kacang hijau Kenari dan No. 129 yang disisipkan 10 dan 5 hari sebelum panen padi gogo, dampak negatif dari iklim mikro yang ditimbulkan seperti rendahnya intersepsi radiasi surya oleh tajuk tanaman, tingginya suhu dan kekurangan air selama fase pertumbuhan dan perkembangan tanaman, telah memicu penurunan hasil yang lebih drastis 0,1 dan 0,3 ton per hektar (Tabel 5).

Bila memperhatikan Tabel 4, Tabel 5, tampak jelas bahwa kedua kultivar kacang hijau (Kenari dan No. 129) memiliki pertumbuhan tinggi tanaman maksimum kedua-duanya lebih rendah dibandingkan dengan potensi genetik tanaman yaitu kisaran $23,87-34,47 \mathrm{~cm}$ vs $55 \mathrm{~cm}$ dan $45 \mathrm{~cm}$, ILD berkisar dari 0,31 - 1,20 sedangkan ILD optimum (3 - 4). Demikian pula yang terjadi terhadap komponen hasil dan hasil, bobot 100 butir kedua kultivar berada dalam kisaran 4,85 - 6,80 gram semua berada di bawah 7 gram, dan bobot biji kering per hektar untuk kedua kultivar berkisar dari $(0,1-0,6)$ ton per hektar, padahal potensi hasil masing-masing kultivar Kenari 1,38 ton per hektar dengan rataan hasil 0,83 - 2,45 ton per hekar, dan No. 129 adalah 1,6 ton per hektar, namun tentu saja keadaan ini berada dalam kondisi lingkungan relatif optimal. Tampak jelas bahwa kejadian tersebut disebabkan oleh dampak negatif dari iklim mikro yang terbentuk, akibat naungan paranet selama fase pertumbuhan dan perkembangan tanaman, dan naungan dari padi gogo setelah waktu penyisipan, seperti faktor lingkungan tumbuh intersepsi radiasi surya, suhu, dan kelembaban serta ketersediaan air yang berasal dari curah hujan berada dalam kondisi tidak optimum.

Hubungan antara penurunan intersepsi radiasi surya dan ILD terhadap penurunan hasil biji kering tertera pada Tabel 6 .

Tabel 6. Hubungan antara Penurunan Intersepsi Radiasi Surya dan ILD terhadap Penurunan Hasil Biji Kering Kacang Hijau.

\begin{tabular}{cccc}
\hline \hline Perlakuan & $\begin{array}{c}\text { Penurunan } \\
\text { intersepsi } \\
\text { radiasi surya *) } \\
\text { (\%) }\end{array}$ & ILD & $\begin{array}{c}\text { Penurunan } \\
\text { hasil biji } \\
\text { kering per } \\
\text { hektar }{ }^{* *} \text { (\%) }\end{array}$ \\
\hline $\mathrm{A}_{25}$ & 82,87 & 1,03 & 56,52 \\
$\mathrm{~A}_{20}$ & 84,68 & 0,93 & 63,77 \\
$\mathrm{~A}_{15}$ & 86,44 & 0,86 & 71,01 \\
$\mathrm{~A}_{10}$ & 88,66 & 0,70 & 78,26 \\
$\mathrm{~A}_{5}$ & 91,48 & 0,41 & 92,75 \\
$\mathrm{~B}_{25}$ & 82,24 & 1,20 & 62,75 \\
$\mathrm{~B}_{20}$ & 85,56 & 0,97 & 68,75 \\
$\mathrm{~B}_{15}$ & 87,31 & 0,72 & 68,75 \\
$\mathrm{~B}_{10}$ & 85,57 & 0,68 & 81,25 \\
$\mathrm{~B}_{5}$ & 92,86 & 0,31 & 93,75 \\
\hline \hline
\end{tabular}

Akibat waktu penyisipan kacang hijau di antara padi gogo berkisar dari 25 hari sebelum panen padi gogo sampai dengan 5 hari sebelum panen, terjadi penurunan intersepsi radiasi surya yang berkisar dari 82,24-92,86\%. Hal ini diikuti dengan rendahnya ILD yang berkisar dari $0,31-1,20$, yang selanjutnya menurunkan hasil biji kering per hektar dari 56,52 - 93,75\%. Kejadian ini sejalan dengan hasil penelitian yang diungkapkan oleh Wolf dan Blaser (1972) pada tanaman Medicago sativa L., dengan berkurangnya intersepsi radiasi surya yang lebih besar dari kisaran 55-73 \% selama periode pertumbuhan tanaman, dapat menurunkan bobot daun spesifik, ILD, dan pertukaran karbon bersih, yang pada gilirannya menurunkan hasil dengan tajam.

Keadaan ini bisa ditolerir sampai dengan pengurangan intersepsi radiasi surya sebesar 
25\%. Dugaan kuat disebabkan tidak aktifnya enzim Rudphase. Kondisi ini diperparah oleh faktor-faktor lainnya selain intersepsi radiasi surya, yaitu suhu, kelembaban dan ketersediaan air, seperti telah diuraikan sebelumnya.

Nisbah Kompetisi merupakan alat ukur (instrument) untuk mengukur kompetisi secara kuantitatif dari tanaman yang ditumpangsarikan, yang dihitung secara sederhana dari suatu pertanaman terhadap pertanaman lain dan koreksi tersebut mengikuti ruang (tempat) yang dirancang untuk setiap pertanaman (Willey dan Rao, 1980).

Dalam penelitian ini kekuatan kompetisi kedua komoditas (padi gogo terhadap kacang hijau dan kacang hijau terhadap padi gogo), masing-masing akan sangat ditentukan oleh besarnya perolehan hasil biji kering pada masing-masing komoditas tumpangsari. Seperti ditunjukkan oleh Tabel 7 pada kacang hijau kultivar Kenari yang disisipkan 25, 20, dan 15 hari sebelum panen padi gogo $\left(\mathrm{A}_{25}, \mathrm{~A}_{20}, \mathrm{~A}_{15}\right)$ memiliki kekuatan kompetisi terhadap padi gogo lebih besar, masing-masing 1,30 vs 0,77 , 1,20 vs 0,83 , dan 1,07 vs 0,92 .

Demikian pula yang terjadi pada kultivar No. 129, kekuatan kompetisi kacang hijau terhadap padi gogo terjadi pada 25 dan 20 hari sebelum panen padi gogo $\left(\mathrm{B}_{25}\right.$ dan $\left.\mathrm{B}_{20}\right)$ masingmasing sebesar 1,30 vs 0,77 dan 1,20 vs 0,83 . Kekuatan kompetisi kacang hijau yang paling rendah terhadap padi gogo, dicapai oleh perlakuan 5 hari sebelum panen padi gogo $\left(\mathrm{A}_{5}\right.$ dan $\mathrm{B}_{5}$ ) baik untuk kultivar Kenari maupun No. 129 sebesar 0,17 vs 6,02. Kekuatan kompetisi bagi tanaman yang ditumpangsarikan akan sangat ditentukan oleh masing-masing hasil tumpangsarinya. Perolehan hasil tumpangsari yang mendekati atau sama dengan tanaman tunggalnya dibandingkan dengan kompetitornya yang hasil tumpangsarinya lebih kecil berbeda jauh dengan tanaman tunggalnya, dapat dipastikan tanaman tersebut memiliki kekuatan kompetisi yang lebih tinggi dibandingkan kompetitornya. Seperti halnya dalam penelitian ini, kacang hijau kultivar Kenari yang disisipkan 25, 20, dan 15 hari sebelum panen padi gogo, dan kultivar No. 129 dengan waktu penyisipan 25 dan 20 hari sebelum panen padi gogo, nisbah kompetisinya lebih besar dibandingkan padi gogo $(>1)$. Hal ini tentu saja tidak lepas dari kondisi iklim mikro yang ditimbulkan akibat adanya naungan paranet dan padi gogo terhadap pertumbuhan dan hasil kedua kultivar kacang hijau, seperti telah diuraikan sebelumnya.

Evaluasi produktivitas pada tumpangsari, termasuk tumpangsari bersisipan dinyatakan dengan Nisbah Kesetaraan Lahan (NKL), yaitu luas relatif lahan pertanaman tunggal yang diperlukan untuk mendapatkan hasil yang sama dengan hasil yang diperoleh pada pertanaman tumpangsari, jika kedua pertanaman tersebut memperoleh tingkat pengelolaan yang sama (Harwood, 1979). Hasil penelitian menunjukkan bahwa semua nilai NKL menunjukkan besaran $>1$, yang mengindikasikan bahwa sistem pertanaman tumpangsari bersisipan kacang hijau di antara padi gogo merupakan sistem produksi alternatif untuk dikembangkan. Namun tentu

Tabel 7. Nisbah Kompetisi Padi Gogo dan Kacang Hijau Serta Nisbah Kesetaraan Lahan Atas Dasar Perhitungan Hasil Tanaman Tunggal dan Tumpangsari Bersisipan Masing-masing Tanaman pada Setiap Pelakuan.

\begin{tabular}{|c|c|c|c|c|c|c|c|}
\hline Perlakuan & $\begin{array}{l}\text { Tunggal } \\
\text { padi gogo } \\
\left(\text { t ha }^{-1)}\right.\end{array}$ & $\begin{array}{c}\text { Tumpangsari } \\
\text { bersisipan } \\
\text { padi gogo } \\
\text { (t ha-1) }\end{array}$ & $\begin{array}{c}\text { Tunggal } \\
\text { kacang } \\
\text { hijau } \\
\left(\text { t ha-1) }^{-1}\right)\end{array}$ & $\begin{array}{c}\text { Tumpangsari } \\
\text { bersisipan } \\
\text { kacang hijau } \\
\left(\mathrm{t} \mathrm{ha}^{-1}\right)\end{array}$ & $\begin{array}{c}\text { Nisbah } \\
\text { Kompetisi } \\
\text { padi gogo } \\
\text { (NK pg) }\end{array}$ & $\begin{array}{c}\text { Nisbah } \\
\text { Kompetisi } \\
\text { Kacang hijau } \\
\text { (NK kh) }\end{array}$ & $\begin{array}{c}\text { Nisbah } \\
\text { Kesetaraan } \\
\text { Lahan } \\
\text { (NKL) }\end{array}$ \\
\hline $\mathrm{A}_{25}$ & 1,3 & 1,0 & 0,6 & 0,6 & 0,77 & 1,30 & 1,77 \\
\hline $\mathrm{A}_{20}$ & 1,3 & 0,9 & 0,6 & 0,5 & 0,83 & 1,20 & 1,53 \\
\hline $\mathrm{A}_{15}$ & 1,3 & 0,8 & 0,6 & 0,4 & 0,92 & 1,07 & 1,27 \\
\hline $\mathrm{A}_{10}$ & 1,3 & 1,2 & 0,6 & 0,3 & 1,85 & 0,54 & 1,42 \\
\hline $\mathrm{A}_{5}$ & 1,3 & 1,3 & 0,6 & 0,1 & 6,02 & 0,17 & 1,17 \\
\hline $\mathrm{B}_{25}$ & 1,3 & 1,0 & 0,6 & 0,6 & 0,77 & 1,30 & 1,77 \\
\hline $\mathrm{B}_{20}$ & 1,3 & 0,9 & 0,6 & 0,5 & 0,83 & 1,20 & 1,53 \\
\hline $\mathrm{B}_{15}$ & 1,3 & 1,1 & 0,6 & 0,5 & 1,02 & 0,98 & 1,67 \\
\hline $\mathrm{B}_{10}$ & 1,3 & 0,8 & 0,6 & 0,3 & 1,23 & 0,83 & 1,11 \\
\hline $\mathrm{B}_{5}$ & 1,3 & 1,3 & 0,6 & 0,1 & 6,02 & 0,17 & 1,17 \\
\hline
\end{tabular}

Keterangan : hspp : hari sebelum panen padi gogo 
saja perolehan NKL $>1$, perlu didukung oleh perolehan masing-masing hasil komoditas tumpangsari yang mampu menampilkan masing-masing potensinya.

\section{Kesimpulan dan Saran}

Rentang waktu penyisipan kacang hijau di antara padi gogo dengan kisaran waktu 25, 20, dan 15 hari sebelum panen padi gogo, menunjukkan pertumbuhan dan hasil kedua kultivar kacang hijau Kenari dan No. 129 lebih baik dibandingkan perlakuan 10 dan 5 hari sebelum panen padi-gogo. Hal ini berdampak lebih baik pula terhadap Nisbah Kompetisi dan Nisbah Kesetaraan Lahan, dengan besaran masing-masing kultivar 1,77; 1,53; 1,27 dan 1,77; 1,53; 1,63.Untuk tanaman sisipan, dapat dikembangkan penelitian serupa pada komoditas lain selain kacang hijau di bawah naungan padi gogo yang sesuai dengan kondisi agroekosistem.

\section{Ucapan Terima Kasih}

Ucapan terimakasih disampaikan kepada Direktur Eksekutif I MHERE Project Universitas Padjadjaran, 2010 atas dukungan finansial untuk melaksanakan penelitian ini, serta semua pihak yang telah membantu penelitian ini.

\section{Daftar Pustaka}

Abdulhay, O. Sulaeman N. 1984. Petunjuk Teknis Penentuan Pola Pertanaman. Dinas Pertanian Propinsi Jawa Barat.

Ahmad Bey dan Irsal Las. 1991. Strategi Pendekatan Iklim dalam Usaha Tani. Kapita Selekta dalam Agrometeorologi. Direktorat Jendral Pendidikan Tinggi Departemen Pendidikan dan Kebudayaan.

Biro Pusat Statistik Indonesia. 2005. Statistik Indonesia Tahun 2004. BPS. Jakarta. 152p.

Carlson, P.S. 1980. The Biology of Crop Productivity. Academic Press, New York: 16-25.
Collins, W. J., R. C. Rossiter, and A. R. Monreal. 1978. The influence of shading on seed yield in subterranean clover. Aust. J. Agric. Res. 29 : 1167-1175.

Fisher, R. A. 1975. Yield potential in a dwarf spring wheat and the effect of shading. Crop Sci. 15 : 607-613.

Justika S. Baharsyah. 1991. Hubungan Cuaca Tanaman. Kapita Selekta dalam Agrometeorologi. Direktorat Jenderal Pendidikan Tinggi, Dep. Pendidikan dan Kebudayaan.

Kamaluddin. 2009. Peremajaan Kelapa Berbasis Usahatani Polikultur Penopang Pendapatan Petani Berkelanjutan. Wikipedia. UNRI. Faperta. Diakses Juni 2009.

Oldeman, L. R., 1975. An Agroclimatic Map. Java CRIA (LP 3). Bogor.

Poehlman, J. M. dan D. A. Sleper. 1995. Breeding Fields Crops Fourth Edition. Iowa State University Press. Ames, Iowa.

Poehlman, John Milton. 1991. The Mungbean. Westview Press. Colorado, United States.

Poneta, F. D. 1977. The effect of shade upon seedling growth in groundsel bush (Baccharis Laktolial) Aust. J. Res. 28: 681-690.

Purwono dan Heni Purnamawati. 2007. Budidaya 8 Jenis Tanaman Pangan Unggul. PT Penebar Swadaya. Jakarta: 21-29.

Sale, P. J. M. 1976. Effect of shading at different times on the growth and yield of the potato. Aust. J. Agric . Res. 27 : 557 - 565.

Shetty, S. V. R., M. V. K Sivakumar, and S. A. Ram. 1982. Effect of shading on the growth of some common weeds of the semi arid tropics. Agron. J. 74 : 1023-1029.

Sitompul, S. M. and Bambang Guritmo. 1995. Analisis Pertumbuhan Tanaman. Fakultas Pertanian Universitas Brawijaya. Gajah Mada University Press, Yogyakarta.

Willey, R. W., and Rao, M.R. 1980. A Competitive Ratio for Quantifying Compe-tition between Intercrops. Experimental Agriculture 16 : $117-125$.

Wolf, D. D., and R. E. Blaster. 1972. Growth rate and physiology of alfalfa as influenced by canopy and light. Crop Sci. 12 : 23-26.

Yuwariah Y. 2011. Dasar-Dasar Sistem Tanam Ganda. Jurusan Budidaya Pertanian, Fakultas Pertanian, Universitas Padjadjaran, Bandung 2011. 